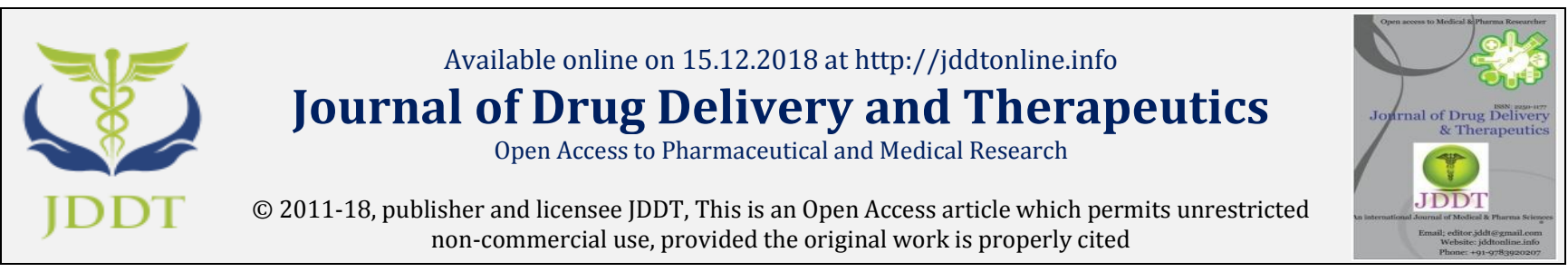

Open $\odot$ Access

Review Article

\title{
Expository aspect for action of Ksharaplota
}

\author{
Anantkumar V. Shekokar ${ }^{*}$, Vijay P. Ukhalkar ${ }^{2}$ \\ ${ }^{1}$ Ph. D. Scholar, Dept. of Shalyatantra, Govt. Ayurveda College, Nanded, Maharashtra, India. \\ ${ }^{2}$ Ph.D. Guide and Professor, Dept. of Shalyatantra, Govt. Ayurved College, Nanded, Maharashtra, India.
}

\begin{abstract}
Kshara Karma or chemical cauterization described in Ayurveda as one of the Anushastras (Minimum Assess Surgery). It is considered superior in all types of Anushstra due to its efficacy in conditions where all other measures failed to cure diseases or surgical interventions. Healing of wounds and cuts is a very difficult if wound or cuts becomes worse and turned to Dushta Varna due to negligence and the inappropriate approaches of treatment. However wound healing is a natural defense mechanism of body but in complicated and severe cases there are need of therapeutic practices toboost healing mechanism of body. Father of Indian surgery Sushruta mentioned use of dressing materials such as; Pichu, Plota, Kawalika and Vikeshika for the management of Dushta Vrana, Plota used to clean \& covers the Vrana very deeply and helps to removes debris of wounds effectively. Considering these all facts present article emphasized mode of action of Ksharaplota (Alkaline Medicated Gauze) for exploring its surgical significance with logical interventions.
\end{abstract}

Keywords: VranaShodhana, VranaRopana, DushtaVrana, Action of Ksharaplota, Alkaline Medicated Gauze.

Article Info: Received 31 Oct, 2018; Review Completed 11 Dec 2018; Accepted 12 Dec 2018; Available online 15 Dec 2018

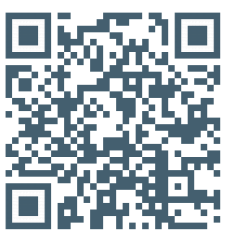

Cite this article as:

Shekokar AV, Ukhalkar VP, Expository aspect for action of Ksharaplota , Journal of Drug Delivery and Therapeutics. 2018; 8(6-s):420-423 DOI: http://dx.doi.org/10.22270/jddt.v8i6-s.2147

*Address for Correspondence:

Anantkumar V. Shekokar, Ph. D. Scholar, Dept. of Shalyatantra, Govt. Ayurveda College, Nanded, Maharashtra, India.

\section{INTRODUCTION}

Ayurveda is a divine science of medicine which described various principlesand theories of management of wound or other traumas and cuts. Ayurveda mentioned Vranashodhana and Vranaropana drugs for the management of cuts or wounds along with different dressing techniques such as; Pichu, Plota and Kawalika etc ${ }^{1-5}$. Plota is very efficient healing technique for wound care since it helps to clean and cover the wound. Ksharaplota (Medicated Gauze) is one of such dressing method used for the management of infected and chronic wounds. Ksharaplota is prepared by using Snuhikshira (Milk of Euphorbia neriifolia Linn.), Apamargakshara (Ash of Achyranthesaspera L.) and Haridra (Curcuma longa L.). These drugs applied as single coating gauze (Plota) over open wounds and ulcers ${ }^{4-8}$. This Ksharaplota offers excellent VranaShodhana and Ropana properties in the treatment of DushtaVrana. Ksharaplota is a simple and safe technique with minimal invasion may also utilize for effective management of Dushtavrana (Infected wound /ulcer).

\section{Preparation of Ksharaplota}

Material required for preparation of Ksharaplota is mentioned below.

1. Snuhikshira (Euphorbia nerifolia)
2. Apamarg Kshara (Achyranthus aspera)

3. Haridra powder (Curcuma longa)

4. Single layer Gauze piece

5. Wooden Ring

6. Cabinet

7. Polythene Bag $(12 \times 8 \mathrm{~cm})$

\section{Method of Ksharaplota preparation}

Round gauze piece, $23 \mathrm{~cm}$ in diameter is fixed in the doubled layered circular wooden ring. This gauze piece is made so tight that the coating can be done uniformly. Initially on $1^{\text {st }}$ day Sunhikshira $50 \mathrm{ml}$ was applied with the help of small cotton swab over the gauze on its whole circumference. The hands should be gloved before smearing. The wet coated gauze with rings should be placed inside cabinet. It was then dried for a day, on the $2^{\text {nd }}$ day dried gauze was again smeared with $50 \mathrm{ml}$ of Snuhikshira and followed by $20 \mathrm{gm}$ of Apamargakshara with cotton swab, let it be dried in a cabinet for a day. On the $3^{\text {rd }}$ day dried gauze was smeared with $50 \mathrm{ml}$ Snuhikshira followed by $20 \mathrm{gm}$ of Haridra powder which was then allowed to dry in the cabinet for a day 1 coating of Snuhikshira required $50 \mathrm{ml}$ quantity, so total quantity of Snuhikshirain Ksharaplota was $150 \mathrm{ml}, 20 \mathrm{gm}$ of 
Apamaragkshara and 20 gm of Haridra powder .

In this way a single coating of each Snuhikshira, Apamargakshara \& Haridra powder were applied to the gauze and cut into $6 \mathrm{~cm}$. $6 \mathrm{~cm}$. pieces of Ksharaplota, it was then sealed in polythene packs. Ksharaplota should be placed in a cabinet under ultra-violet light for safety storage as well as sterilization. The ingredient used to prepare Ksharaplota mentioned in Figure 1.

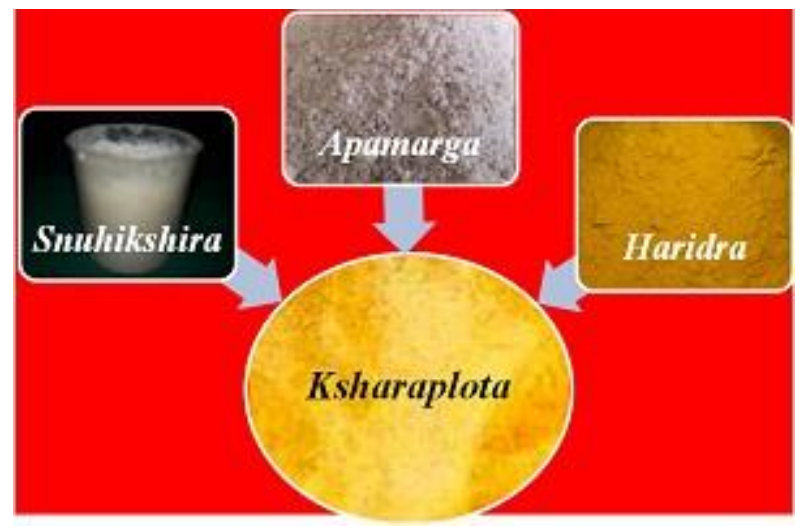

Figure 1: Ingredients used to prepare Ksharaplota.

\section{Therapeutic action of Ksharaplota dressing}

* It helps in curetting, draining and healing of wound.

* It removes unhealthy tissue.

* Promotes healing due to caustic action.

* Controls infection due to aseptic and its anti-microbial action.

* Separate debris and clean wound thus boost natural process of tissue healing.

* Offer anti-inflammatory effect thus relieves pain.

\section{Probable Mode of action of Ksharaplota}

Ksharaplota composed of Snuhi \& Apamaraga has Ksharan and Kshanan properties, Apamargakshara also cauterize tissue by its Ksharana Guna while Haridra offers Krimighana \& Ropana properties thus provides VranaShodhana \& VranaRopana effect. Chemical properties of Ksharaplota remove unhealthy tissue and alkaline nature of Kshar offers aseptic and antimicrobial effect thus reduces chance of secondary infection ${ }^{3-7}$.

Snuhi component of Ksharaplota provides moisturizing effect due to its sticky property which ultimately promotes epidermal migration resulting enhanced synthesis of connective tissue. The Snuhi latex having binding property therefore retains surgical benefits (debridement, scrapping, hemostatic, aseptic, antiseptic and healing effect) of Apamargakshara for longer time.

Snuhikshira, Apamargakshara and Haridra support biological action of each other and not contraindicated when applied together. Sustained release action of Ksharaplota medication releases ingredient slowly and make available medicine for longer duration to achieve complete healing of chronic wound $6-10$.

\section{Contribution of Ksharaplota ingredient towards its mode of action:}

Ksharaplota overall possess penetrating, scrapping, draining, debridement, sclerosing, healing, antibacterial and antiinflammatory effect in the management of wound and cuts ${ }^{9-}$ 13 .

All three ingredients contribute significantly towards mode of action as follows:

1. Snuhi (Latex of Euphorbia nerifolia) Kshira possess properties such as; Lekhana, Vedanasthapana, Rakthashodhak and Vishaghana due to Katu \& Tikshana Rasa and Ushna Virya. The latex of plant also found to have rubifacient, irritant and powerful caustic action when applied to a raw surface; it also offers analgesic, anti-inflammatory, wound healing and antibacterial activity. It is believe that Euphorbia neriifolia enhances wound healing process by promoting tensile strength, epithelization and angiogenesis.

2. Apamarga (Achyranthus aspera) Kshara offers Lekhana, Chedana, Bhedana, Ropana, Kushtaghna, Shodhana and Krumighana properties due to Katu \& lavana Rasa and Ushna Virya. Katu Rasa contributes towards Shonit Sanghat Bhinnati action of Apamarg Kshara which breakdown pus pockets and blood clots at the site of Vrana. Apamarg Kshara also possesses analgesic, antiinflammatory, hemostasis and antibacterial activity which offers symptomatic relief in Vrana.

3. Tikta \& Laghu Guna and Ushanya Virya of Haridra (Curcuma longa) provides Varnya, Sandhana, Vedanashamaka, Raktastambak, Raktashuddhikar and Lekhana properties. It enhances capillaries vasodilation when applied locally thus facilitates wound debridement (Shodhana) and wound healing (Ropana) process. It also possesses anti-inflammatory, analgesic and antibacterial activity.

\section{Role of Kshara Plota ingredients for its action}

Kshara having Ushna, piercing and scraping nature it also possessing Ksharana and Kshanana properties thus help to destroy lesion. Ksharana properties mobilize deformed skin $\&$ flesh thus removes unwanted tissue debris and offers cleansing effect. Ushna, Tikshna, Sukshma and vyavayi properties of Ksharaplota help to remove blockage of strotorodha, stimulates process of Dathvagni and provides Amapachana effects thus removes toxins. Ashukari property of Kshara resulted instant initiation of healing effect. Ushna Veerya and Vyavayi, Tikshnaguna also help in drug penetration and control vitiated Doshas internally. ${ }^{10-14}$ Long term application of ksharaplota releases ingredients continuously to the applied area and transmitted to Tvak, Sirasnayu, Asthi and Sandhi according to Uapasnehana Nyaya thus offers complete relief. Strangulation of the blood vessel offers ischemic necrosis and debridement of unhealthy tissue which prevents formation of slough and boosts natural process of tissue repair ${ }^{15-20}$. The overall mode of action of Ksharaplota depicted in Figure 2 as follows: 


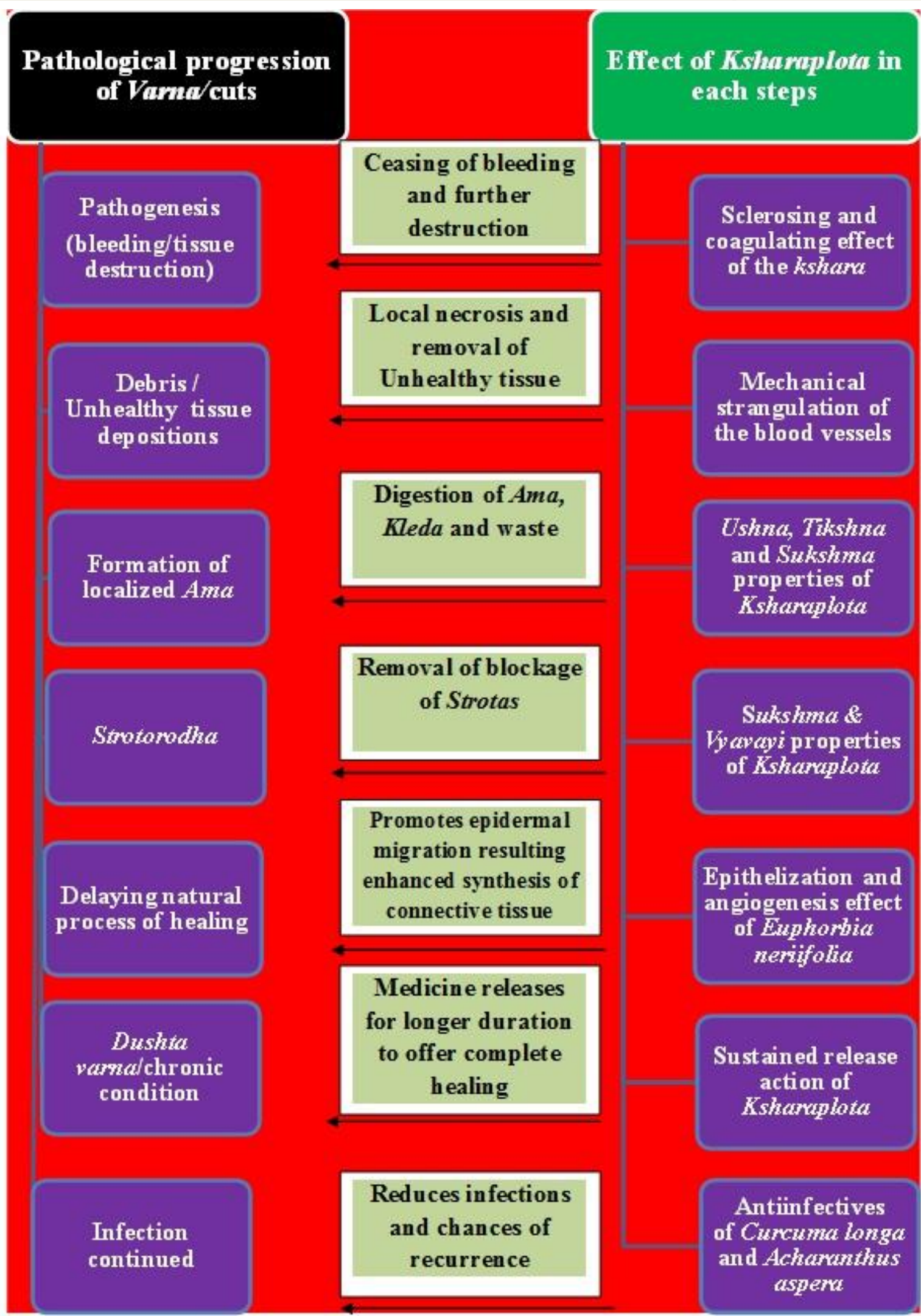

Figure 2: Suggested mode of action of Ksharaplota.

\section{CONCLUSION}

Ksharaplota is a parasurgical approach used extensively for the management of infected wound. The treatment with Ksharaplota reduces chances of recurrence and it possesses great ability to treating chronic wound. The chemical potency of Ksharaplota offers advantage in the management of Vrana with minimal invasion. Therefore Ksharapolta (Alkaline Medicated Gauze) therapy accepted widely in the management of chronic and infective stages of wound. Ksharaplota also helps in emergency condition as a dressing material for cleaning of infected cuts or wound. The novel and established application of Ksharaplota is an important and efficient modality of Shalyatantra in Ayurveda. 


\section{REFERENCES}

1. Dr. Anantram Sharma, Sushruta Samhita Part-2, Chokhamba Surbharati Prakashan, Varanasi, 1st Edition, 2004, P-159.

2. Prof. Sudarshana Shashtri and Prof. Kaviratna Sharma, Original Text and Dalhana's Nibandhasangraha Commentary With Hindi

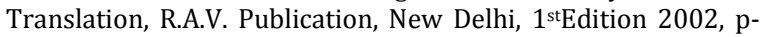
84.

3. Shastri A.Sutra Sthana. 4. Vol. 33. Varanasi: Chaumbika Sanskrit Sansthan; 2001. Sushrutacharya, Sushruta Samhita, Ayurved Tatva Sandipika; pp. 126-7.

4. Shastri A. Chikitsa Sthana. $11^{\text {th }}$ ed. 03. Vol. 6. Varanasi: Published Chaukhamba Sanskrit Sansthan; 1953. Sushrutaacharya, Sushruta Samhita Dalhanacharya Kaviraj; p. 35.

5. Manju Rani, Riju Agrawal, Preparation of different types of Kshara Sutra, Int. J. of research in Ayurveda and Pharmacy, March -April 2016; 7(2).

6. Shastri A. Chikitsa Sthan. 5. Vol. 6. Varanasi: Chaumbika Sanskrit Sansthan; 2001. Sushrutacharya, SushrutaSamhita, Ayurved Tatva Sandipika; p. 36.

7. Sharma SK, Sharma KR, Singh K. Kshara Sutra Therapy in fistula-in-ano and other anorectal disorders. Rashtriya Ayurved Vidyapeeth (National Academy of Ayurveda): RAV-Publication; 1994-95. pp. 161-7.

8. P. Hemantha Kumar and M. Sahu, Role of Aragvadhadi Sutra in the Management of Fistula-in-ano, Ancient Science of Life, 2000, Vol. XIX (3\&4):110-112.

9. Mahesh Kumar ES, Hemantha Kumar P, A case discussion on effect of Palasha Kshara Sutra in the management of Bhagandara (Fistula-in-ano) with special reference to itsAntimicrobial effect, International Journal of Ayurvedic Medicine, 2013, 4(3):242-244.

10. Rath Sudiptkumar, Nagar Lalit, Review of source plants of kshara for ksharasutra preparation for the management of fistula in ano, Int. J. of research in Ayurveda and Pharmacy, May-June 2012; 3(3).

11. Sharma S K, Sharma K R, Singh K, Ksharasutra Therapy In Fistula -In-Ano and Other Anorectal Disorders: Rastriya Ayurved Vidyapeeth; 1994-95, P. 43-59.

12. Sharma S.K, Sharma K.R, Singh K. Kshara Sutra Therapy in Fistula-in-ano and other Ano- Rectal Disorders. New Delhi; R.A.V. Publication; 1995.

13. Anantkumar V. Shekokar, Vijay Ukhalkar. Management of infected wound with Ksharaplota dressing -A Case Study Ayushdhara, April 2018; 5 (2).

14. Acharya Y.T., Nibandhasangraha by Dalhana, commentary on Sushruta Samhita, Chaukhamba Oreintalia, Varanasi, 1997, Sutrasthana $11 / 12$

15. Shastri A, Sushruta Samhita by Sushruta, Chaukhamba Surbharti Prakashana, Varanasi, reprint, 2007, Sutrasthana $11 / 5$.

16. Prof. Sudarshana Shashtri \& Prof, Kaviratna Sharma, Original Text And Dalhana's Nibandhasangraha Commentary With Hindi Translation, R.A.V. Publication, New Delhi, $1^{\text {st }}$ Edition 2002, p-192.

17. Anantkumar V. Shekokar, Kanchan M. Borkar. Innovation of Ksharaplota (medicated gauze) in the Management of Vrana (Ulcer). Int. J. Ayur. Pharma Research 2013; 1 (2):

18. Dr. Anantram Sharma, Sushruta Samhita Part-1, Chokhamba Surbharati Prakashan, Varanasi, 1st Edition, 2004, P-154.

19. Anantkumar V. Shekokar, Vijay Ukhalkar. Formulation and physicochemical characterization of Ksharaplota (medicated gauze) dressing for Vrana Chikitsa. Int. J. Ayur. Pharma Research, July 2018; 6 (7).

20. ShrutiPandey, VinamraSharam, A critical review on Historical aspect of Kshara, Int. J. of research in Ayurveda and Pharmacy, Jully-Augest 2016; 7(3). 